\title{
Penerapan Algoritma Naïve Bayes Classifier dalam Memprediksi Status Keberlanjutan Polis Nasabah Asuransi PT.X
}

\author{
Ajeng Mega Pratiwi", Aceng Komarudin Mutaqin \\ Prodi Statistika, Fakultas Matematika dan Ilmu Pengetahuan Alam, \\ Universitas Islam Bandung, Indonesia. \\ *pratiwiajengmega2104@gmail.com, Aceng.k.mutaqin@gmail.com
}

\begin{abstract}
This article discusses the classification in predicting the sustainability status of the health insurance customer policy of PT. X uses the Naïve Bayes Classifier Algorithm. In predicting the Naive Bayes Classifier Algorithm, it uses the concepts and theories of data mining in the literature related to insurance by calculating the probability of each class of variables using the Bayes theorem in describing the performance of a model or algorithm specifically using the Confusion Matrix. To be able to predict the decisions of health insurance customers in the policy sustainability status, a method of data analysis of registered insurance customers is needed. The data used is data obtained from the insurance company PT. X. The data contains customer information data in the form of 9 variables (Policy Number, Smoking Status, Gender, Age, Marital Status, Dependents, Monthly Premiums, Current Status / whether or not premium payments and insurance policy renewal status). The results of the application of the Naïve Bayes Classifier Algorithm show that the algorithm is quite good in predicting the status of the policy extension of the insured health insurance PT. X, with an average accuracy of $85.82 \%$, an average precision of $96.10 \%$ and an average recall of 93.55 .
\end{abstract}

Keywords: Classification, Nä̈ve Bayes, Prediction of Health Insurance Policy Renewal.

Abstrak. Artikel ini membahas tentang klasifikasi dalam memprediksi status keberlanjutan polis nasabah asuransi kesehatan PT. X menggunakan Algoritma Nave Bayes Classifier. Dalam memprediksi Algoritma Naive Bayes Classifier menggunakan konsep dan teori data mining dalam literatur yang berhubungan dengan asuransi dengan menghitung probabilitas setiap kelas variabel menggunakan teorema Bayes dalam menggambarkan kinerja suatu model atau algoritma secara khusus menggunakan Confusion Matrix . Untuk dapat memprediksi keputusan nasabah asuransi kesehatan dalam status kesinambungan polis, diperlukan suatu metode analisis data nasabah asuransi yang terdaftar. Data yang digunakan adalah data yang diperoleh dari perusahaan asuransi PT. X. Data tersebut berisi data informasi nasabah berupa 9 variabel (Nomor Polis, Status Merokok, Jenis Kelamin, Usia, Status Perkawinan, Tanggungan, Premi Bulanan, Status Lancar/tidaknya pembayaran premi dan status perpanjangan polis asuransi). Hasil penerapan Algoritma Naïve Bayes Classifier menunjukkan bahwa algoritma tersebut cukup baik dalam memprediksi status perpanjangan polis dari tertanggung asuransi kesehatan PT. X, dengan rata-rata akurasi 85,82\%, presisi rata-rata 96,10\% dan rata-rata recall 93,55.

Kata Kunci: Klasifikasi, Nave Bayes, Prediksi Perpanjangan Polis Jaminan Kesehatan. 


\section{A. Pendahuluan}

Analisis regresi adalah suatu kajian analisis pada hubungan antara variabel yang biasa disebut dengan variabel bebas (variabel prediktor) terhadap variabel tak bebas (variabel respon) (Gujarati, 2006). Salah satu bentuk paling umum dari bentuk Count Regression ialah Regresi Poisson. Regresi poisson merupakan suatu metode regresi yang biasa digunakan menganalisis data dengan variabel responnya berupa data diskrit. Dalam regresi poisson terdapat asumsi yang harus dip Indonesia Setiap manusia akan selalu dihadapkan pada peristiwa yang tidak menentu dalam hidupannya. Peristiwa tersebut seringkali disebut dengan risiko. Hal ini termasuk dalam masalah keuntungan atau kerugian yang dihadapi. Contohnya kecelakaan, kebakaran, hilang, rusak, sakit, meninggal dan lain sebagainya yang mungkin bisa saja terjadi. Untuk mengganti atau menyeimbangkan kembali, asuransi merupakan sarana perlindungan dari kerugian finansial.

Asuransi adalah perjanjian antara dua pihak, pihak pertama disebut penanggung atau perusahaan asuransi dan pihak kedua disebut tertanggung sebagai pemegang polis. Asuransi juga dapat diartikan bentuk jaminan resiko yang mungkin saja terjadi di masa yang akan datang dengan nominal biaya yang tidak sedikit (Ignatius, 2018). Oleh sebab itu dibutuhkan asuransi dalam menjamin sesuatu yang berharga agar mendapatkan langkah preventif sebagai jaminan jika terjadi suatu yang tidak diinginkan. Untuk memperoleh jaminan asuransi atau risiko yang mungkin terjadi, maka pemegang polis atau tertanggung diwajibkan membayar sejumlah uang yang sering disebut premi dalam jangka waktu tertentu yang sudah ditentukan. Polis asuransi merupakan sebuah bukti perjanjian tertulis yang dilakukan oleh pihak perusahaan asuransi (penanggung) dengan nasabah pengguna layanan asuransi (tertanggung). Polis asuransi merupakan hal yang sangat penting di dalam layanan asuransi itu sendiri, karena polis asuransi akan melindungi setiap hak dan kewajiban nasabah dan juga pihak perusahaan asuransi dalam jangka waktu tertentu. Sehingga nasabah harus pintar dalam menentukan perusahaan asuransi yang dipilih.

Penawaran asuransi tidak terbatas pada orang-orang yang terpelajar dan memiliki pendapatan besar, tetapi semua golongan masyarakat dapat turut serta didalamnya. Produk asuransi yang ditawarkan perusahaan asuransi juga semakin bermacam-macam seiring berkembangnya peradaban masyarakat dan resiko hidup yang semakin tinggi. Mulai dari produk asuransi jiwa, asuransi pendidikan, dan asuransi kesehatan. Semakin banyaknya persaingan dalam bisnis asuransi membuat perusahaan asuransi dituntut memiliki inovasi dalam mempertahankan bahkan meningkatkan jumlah nasabahnya. Disisi lain, keputusan nasabah asuransi kesehatan terhadap keberlanjutan polis asuransi yang telah dimiliki tidaklah mudah untuk diprediksi. Untuk dapat memprediksi keputusan nasabah asuransi kesehatan dalam memperpanjang polis yang dimiliki maka diperlukan suatu metode analisis pada data nasabah asuransi yang telah terdaftar. Dalam dunia asuransi akan selalu dihadapkan dengan permasalahan yang sering timbul yaitu banyaknya nasabah yang tidak lancar dalam membayar premi dan memutuskan untuk tidak memperpanjang polis asuransinya. Bahkan ada nasabah yang pindah dari satu perusahaan asuransi ke perusahaan asuransi lain karena produk di perusahaan asuransi lain lebih menarik dan menguntungkan.

Algoritma Nä̈ve Bayes Classifier merupakan cara untuk memprediksi status keberlanjutan polis nasabah asuransi dengan klasifikasi data nasabah. Teknik klasifikasi suatu proses untuk menemukan model atau fungsi yang menjelaskan atau membedakan kelas dari suatu objek (Natalius, 2011). Pemanfaaatan algoritma Nä̈ve Bayes sebagai salah satu algoritma terbaik dalam data mining klasifikasi untuk memprediksi keputusan nasabah asuransi terhadap polis asuranssi yang telah dimiliki. Tujuan penelitian ini adalah menerapkan metode algoritma Naive Bayes Classifier dalam memprediksi status keberlanjutan polis nasabah asuransi kesehatan PT. X. Dalam proses evaluasi Algoritma Nä̈ve Bayes Classifier yang dihasilkan, digunakan alat analisis yaitu Confusion Matrix untuk menggambarkan performa dari sebuah model atau algoritma secara spesifik (Kuncahyo, 2019). Setiap kolom dari matrix tersebut, mempresentasikan kelas aktual dari data, dan setiap kolom mempresentasikan kelas prediksi dari data dengan informasi akurasi, presisi dan recall dari hasil Algoritma. 


\section{B. Metodologi Penelitian \\ Metode Pengumpulan Data}

Pada penelitian ini menggunakan Data yang digunakan pada penelitian ini adalah sebanyak 92 pengamatan berisikan data informasi tertangggung polis asuransi kesehatan PT. X berupa 9 variabel (Nomor Tertanggung, Status Merokok, Jenis Kelamin, Usia, Status Perrnikahan, Tanggungan, Premi perbulan, Status Lancar/ tidaknya pembayaran premi dan Status Perpanjangan Polis). Data tersebut akan dibagi menjadi 2 yaitu data training dan data testing, dimana pengamatan yang masuk kedalam data training dan data testing dilakukan secara acak. Proporsi untuk data training yaitu sebesar $70 \%$ dari data keseluruhan atau sebanyak 64 pengamatan. Sedangkan proporsi untuk data testing yaitu sebesar $30 \%$ dari data keseluruhan atau sebanyak 28 pengamatan.

\section{Tahapan Analisis Data}

Membagi proporsi data nasabah menjadi 2 bagian kelompok data. yaitu sebagai data latih (Proses Training) dan sebaagi data uji (Proses Testing):

\section{Analisis Data Training}

1. Membaca data nasabah asuransi yang akan digunakan sebagai data training.

2. Memeriksa bentuk dari setiap kriteria nasabah asuransi, baik yang bertipe numerik/kontinyu maupun yang berbentuk kategorik.

3. Jika data berbentuk numerik, maka hitung mean dan standar deviasi tiap atribut.

Jika data bersifat kategorik, maka langkah selanjutnya yaitu menghitung probabilitas prior tiap kelasnya.

berikut:

Rumus nilai probabilitas Nä̈ve Bayes Classifier dapat ditulis dalam bentuk persamaan

$$
P(\mathrm{C} \mid \mathrm{F})=\frac{\mathrm{P}(\mathrm{F} \mid \mathrm{C}) \mathrm{P}(\mathrm{C})}{P(F)}
$$

dimana,

$\mathrm{F} \quad=$ Data dengan kelas yang belum diketahui

$\mathrm{C} \quad=$ Hipotesis data $\mathrm{F}$ merupakan suatu kelas spesifik

$P(\mathrm{C} \mid \mathrm{F})=$ Probabilitas hipotesis $\mathrm{C}$ berdasarkan kondisi $\mathrm{F}$

$P(\mathrm{~F} \mid \mathrm{C})=$ Probabilitas $\mathrm{F}$ berdasarkan hipotesis $\mathrm{C}$

$P(\mathrm{C})=$ Probabilitas awal (prior) hipotesis $\mathrm{C}$

$P(\mathrm{~F})=$ Probabilitas awal (prior) dari $\mathrm{F}$

Pada Algoritma Nä̈ve Bayes Classifier data dengan tipe numerik (kontinyu) dapat dihitung dengan cara mengasumsikan bentuk tertentu dari distribusi probabilitas untuk fitur kontinu dan memperkirakan parameter distribusi dengan data training. Distribusi normal dikarakteristikkan dengan dua parameter, yaitu nilai rata-rata $(\mu)$ dan nilai varians $\left(\sigma^{2}\right)$. Untuk setiap kelas $y_{j}$, probabilitas bersyarat kelas $y_{j}$ untuk data $x_{i}$ adalah:

$$
P\left(X_{i}=x_{i} \mid Y_{j}=y_{j}\right)=\frac{1}{\sigma_{i j} \sqrt{2 \pi}} e^{-\frac{\left(x_{i j}-\mu_{i j}\right)^{2}}{2 \sigma_{i j}^{2}}}
$$

Keterangan:

$\mathrm{P} \quad=$ Probabilitas

$X_{i} \quad=$ Atribut ke $\mathrm{i}$

$x i \quad=$ Nilai atribut ke $\mathrm{i}$

$Y_{j} \quad=$ Kelas yang dicari

$y_{j} \quad=$ Sub kelas Y yang dicari

$\mu_{i j} \quad=$ Nilai rata-rata dari seluruh atribut

$\sigma_{i j} \quad=$ Varians dari seluruh atribut

dimana,

$$
\mu_{i j}=\frac{\sum_{i=1}^{n_{j}} x_{i j}}{n_{j}}
$$




$$
\sigma^{2}{ }_{i j}=\frac{\sum_{i=1}^{n_{j}}\left(x_{i j}-\mu_{i j}\right)^{2}}{n_{j}}
$$

Selanjutnya, dalam mengukur performa Algoritma Nä̈ve Bayes Calssifier menggunakan confusion matrix dapat diperoleh data-data lain yang sangat berguna untuk mengukur perfoma sebuah algoritma, diantaranya:

Akurasi merupakan persentase ketepatan prediksi data yang diklasifikasikan secara benar setelah dilakukan pengujian pada hasil.

$\frac{\mathrm{TP}+\mathrm{TN}}{\text { Total }}$

Presisi merupakan Rasio prediksi benar positif dibandingkan dengan keseluruhan hasil yang diprediksi positif atau ketika model memprediksi positif, seberapa sering prediksi itu benar.

$$
\frac{\mathrm{TP}}{\mathrm{TP}+\mathrm{FP}}
$$

Recall merupakan Rasio prediksi benar positif dibandingkan dengan keseluruhan data yang benar positif atau ketika kelas aktualnya positif, seberapa sering model memprediksi positif.

$$
\frac{\mathrm{TP}}{\mathrm{TP}+\mathrm{FN}}
$$

Analisis Data Testing

1. Menganalisa data uji dengan menghitung probabilitas bersyarat setiap kriteria.

2. Mencari nilai peluang bersyarat tiap atribut.

3. Untuk data tipe numerik (kontinyu) klasifikasi dapat dilakukan dengan rumus Densitas Gaussian.

4. Kemudian, hitung dua parameter pada Distribusi Gaussian yakni mean $(\mu)$ dengan menggunakan Persamaan (2.8) dan varian $(\sigma 2)$ dengan menggunakan.

5. Menemukan model Teorema Algoritma Nä̈ve Bayes Classifier.

6. Setelah model prediksi telah diibangun pada data training tahap selanjutnya adalah mengklasifikasi data yang belum diketahui label kelasnya.

7. Menentukan peluang kelas bersyarat $P\left(X_{i}=x_{i} \mid\right.$ Perpanjang Polis $), P\left(X_{i}=x_{i} \mid\right.$ Tidak Perpanjang Polis) yang dihasilkan dari proses training.

8. Menghitung probabilitas posterior pada data uji, menggunakan.

9. Menentukan label kelas.

10. Membuat Confusion Matrix

11. Menghitung keakurasian performa dari sebuah model atau algoritma secara spesifik

12. Menghitung presisi atau membandingkan rasio positif dengan keseluruhan hasil yang diprediksi positif

13. Menghitung Recall/sensitifitas untuk membandingkan rasio benar positif dengan keseluruhan data yang benar positif

14. Penarikan kesimpulan.

\section{Hasil Penelitian dan Pembahasan}

Menghitung probabilitas prior dari data tertanggung polis asuransi kesehatan PT.X yang termasuk dalam data training. Gambar 1. menyajikan sintaks perangkat lunak R Studio serta outputnya untuk menghitung nilai probabilitas prior. 
naiveBayes.default $(x=X, y=Y$, 1aplace $=$ 1aplace $)$

\section{A-priori probabilities:}

Gambar 1 sintaks dan output perangkat lunak R Studio untuk nilai probabilitas prior.

Berdasarkan Gambar 1 di atas, dapat dilihat bahwa nilai probabilitas prior bahwa tertanggung akan memperpanjang polis yaitu sebesar $47 / 64=0,7344$. Sedangkan nilai probabilitas prior bahwa tertanggung tidak akan memperpanjang polis yaitu sebesar 17/64 = 0,2656 .

Langkah selanjutya menghitung probablitas bersyarat untuk atribut kategorik. Dengan dibantu perangkat lunak Excel, Tabel 1 sampai dengan Tabel 5 menyajikan nilai probabilitas bersyarat untuk atribut status merokok, jenis kelamin, status menikah, tanggungan dan status pembayaran premi.

Tabel 1 Probabilitas Tertanggung dengan Atribut Status Merokok

\begin{tabular}{|c|c|c|}
\hline \multicolumn{3}{|c|}{ PROBABILITAS TERTANGGUNG } \\
\hline P (Merokok|Tidak Merokok) & Perpanjang Polis & Tidak perpanjang Polis \\
\hline Ya & 0,0213 & 0,1176 \\
\hline Tidak & 0,9787 & 0,8824 \\
\hline & 1 & 1 \\
\hline
\end{tabular}

Berdasarkan Tabel 1 di atas, dapat dilihat bahwa nilai probabilitas tertanggung statusnya merokok dengan syarat tertanggung tersebut memperpanjang polis di tahun 2020 yaitu sebesar $1 / 47=0,0213$. Nilai probabilitas bahwa tertanggung statusnya merokok dengan syarat tertanggung tersebut tidak memperpanjang polis di tahun 2020 yaitu sebesar 2/17 =0,1176. Nilai probabilitas bahwa tertanggung statusnya tidak merokok dengan syarat tertanggung tersebut memperpanjang polis di tahun 2020 yaitu sebesar $46 / 47=0,9787$. Nilai probabilitas bahwa tertanggung statusnya tidak merokok dengan syarat tertanggung tersebut tidak memperpanjang polis di tahun 2020 yaitu sebesar $15 / 17=0,8824$.

Tabel 2 Probabilitas Tertanggung dengan Atribut Jenis Kelamin

\begin{tabular}{|c|c|c|}
\hline \multicolumn{3}{|c|}{ FREKUENSI TERTANGGUNG } \\
\hline P(Laki-laki|Perempuan) & Perpanjang Polis & Tidak perpanjang Polis \\
\hline Laki-laki & 31 & 7 \\
\hline Perempuan & 16 & 10 \\
\hline & 47 & 17 \\
\hline
\end{tabular}

Berdasarkan Tabel 2 di atas, dapat dilihat bahwa tertanggung berjenis kelamin laki-laki dengan syarat tertanggung tersebut memperpanjang polis di tahun 2020 yaitu sebesar $31 / 47=$ 0,6596 . Nilai probabilitas bahwa tertanggung berjenis kelamin laki-laki dengan syarat tertanggung tersebut tidak memperpanjang polis di tahun 2020 yaitu sebesar 7/17 =0,4118. Nilai probabilitas bahwa tertanggung berjenis kelamin perempuan dengan syarat tertanggung tersebut memperpanjang polis di tahun 2020 yaitu sebesar $16 / 47=0,3404$. Nilai probabilitas bahwa tertanggung berjenis kelamin perempuan dengan syarat tertanggung tersebut tidak memperpanjang polis di tahun 2020 yaitu sebesar 10/17 =0,5882.

Tabel 3 Probabilitas Tertanggung dengan Atribut Status Menikah

\begin{tabular}{|l|l|l|}
\hline \multicolumn{3}{|c|}{ PROABILITAS TERTANGGUNG } \\
\hline P (Menikah|Belum Menikah) & Perpanjang Polis & Tidak perpanjang Polis \\
\hline
\end{tabular}




\begin{tabular}{|c|c|c|} 
Menikah & 0,4681 & 0,4706 \\
\hline Belum Menikah & 0,5319 & 0,5294 \\
\hline & 1 & 1 \\
\hline
\end{tabular}

Berdasarkan Tabel 3 di atas, dapat dilihat bahwa tertanggung statusnya menikah dengan syarat tertanggung tersebut memperpanjang polis di tahun 2020 yaitu sebesar 22/47 =0,4681 . Nilai probabilitas bahwa tertanggung statusnya menikah dengan syarat tertanggung tersebut tidak memperpanjang polis di tahun 2020 yaitu sebesar $8 / 17=0,4706$. Nilai probabilitas bahwa tertanggung statusnya belum menikah dengan syarat tertanggung tersebut memperpanjang polis di tahun 2020 yaitu sebesar $25 / 47=0,5319$. Nilai probabilitas bahwa tertanggung statusnya belum menikah dengan syarat tertanggung tersebut tidak memperpanjang polis di tahun 2020 yaitu sebesar $9 / 17=0,5294$.

Tabel 4 Probabilitas Tertanggung dengan Atribut Tanggungan

\begin{tabular}{|c|c|c|}
\hline \multicolumn{3}{|c|}{ PROBABILITAS TERTANGGUNG } \\
\hline $\begin{array}{c}\text { P (Ada Tanggungan|Tidak Ada } \\
\text { Tanggungan) }\end{array}$ & $\begin{array}{c}\text { Perpanjang Pol } \\
\text { is }\end{array}$ & $\begin{array}{c}\text { Tidak perpanjang Pol } \\
\text { is }\end{array}$ \\
\hline Ada & 0,4255 & 0,5882 \\
\hline Tidak & 0,5745 & 0,4118 \\
\hline & 1 & 1 \\
\hline
\end{tabular}

Berdasarkan Tabel 4 di atas, dapat dilihat bahwa nilai probabilitas tertanggung yang memiliki tanggungan dengan syarat tertanggung tersebut memperpanjang polis di tahun 2020 yaitu sebesar $20 / 47=0,4255$. Nilai probabilitas bahwa tertanggung yang memiliki tanggungan dengan syarat tertanggung tersebut tidak memperpanjang polis di tahun 2020 yaitu sebesar $10 / 17=0,5882$. Nilai probabilitas bahwa tertanggung yang tidak memiliki tanggungan dengan syarat tertanggung tersebut memperpanjang polis di tahun 2020 yaitu sebesar 27/47 =0,5745. Nilai probabilitas bahwa tertanggung yang tidak memiliki tanggungan dengan syarat tertanggung tersebut tidak memperpanjang polis di tahun 2020 yaitu sebesar 7/17 $=0,4118$.

Tabel 5 Probabilitas Tertanggung dengan Atribut Status Pembayaran Premi

\begin{tabular}{|c|c|c|}
\hline \multicolumn{3}{|c|}{ PROBABILITAS TERTANGGUNG } \\
\hline P (Lancar|Tidak Lancar) & Perpanjang Polis & Tidak perpanjang Polis \\
\hline Lancar & 0,8936 & 0,5294 \\
\hline Tidak Lancar & 0,1064 & 0,4706 \\
\hline & 1 & 1 \\
\hline
\end{tabular}

Berdasarkan Tabel 5 di atas, dapat dilihat bahwanilai probabilitas tertanggung yang status pembayaran preminya lancar dengan syarat tertanggung tersebut memperpanjang polis di tahun 2020 yaitu sebesar $42 / 47=0,8936$. Nilai probabilitas bahwa tertanggung yang status pembayaran preminya lancar dengan syarat tertanggung tersebut tidak memperpanjang polis di tahun 2020 yaitu sebesar $9 / 17=0,5294$. Nilai probabilitas bahwa tertanggung yang status pembayaran preminya tidak lancar dengan syarat tertanggung tersebut memperpanjang polis di tahun 2020 yaitu sebesar $5 / 47=0,1064$. Nilai probabilitas bahwa tertanggung yang status pembayaran preminya tidak lancar dengan syarat tertanggung tersebut tidak memperpanjang polis di tahun 2020 yaitu sebesar 8/17 =0,4706.

Selanjutnya, akan dihitung nilai probabilitas bersyarat untuk atribut numerik. Dalam data tertanggung polis asuransi kesehatan di PT. X tahun 2020 terdapat 2 atribut numerik yaitu usia dan pembayaran premi per bulan. Pada atribut usia nilai rata-rata usia tertanggung yang memperpanjang polis asuransi kesehatan di tahun 2020 yaitu sebesar $\mu_{i j}=33$,

sedangkan nilai rata-rata usia tertanggung yang tidak memperpanjang polis asuransi kesehatan di tahun 2020 yaitu sebesar $\mu_{i j}=36,4706$. Dan nilai varians usia tertanggung yang memperpanjang polis asuransi kesehatan di tahun 2020 yaitu sebesar $\sigma^{2}{ }_{i j}=383,4348$. Sedangkan, nilai varians usia tertanggung yang tidak memperpanjang polis asuransi kesehatan di tahun 2020 yaitu sebesar $\sigma^{2}{ }_{i j}=258,1397$. Dihitung nilai fungsi probabilitas usia untuk 
contoh tertanggung usia 23 tahun,

$$
\begin{aligned}
& f(\text { usia }=23 \mid \text { perpanjang polis })=\frac{1}{19,5815 \sqrt{2 \pi}} e^{-\frac{(23-33)^{2}}{2(383,4348)}}=0,0179 \\
& f(\text { usia }=23 \mid \text { tidak perpanjang polis })=\frac{1}{16,0667 \sqrt{2 \pi}} e^{-\frac{(23-36,4706)^{2}}{2(258,1397)}}=0,0175
\end{aligned}
$$

Berdasarkan perhitungan di atas dapat dilihat bahwa tertanggung usia 23 tahun dengan syarat perpanjang polis asuransi kesehatan di tahun 2020 memiliki nilai fungsi probabilitas sebesar 0,0179 . Sedangkan tertanggung usia 23 tahun dengan syarat tidak perpanjang polis asuransi kesehatan di tahun 2020 memiliki nilai fungsi probabilitas sebesar 0,0175.

Selanjutnya, akan dihitung nilai probabilitas bersyarat untuk atribut pembayaran premi per bulan. Pada atribut pembayaran premi per bulan didapat nilai rata-rata premi per bulan tertanggung yang memperpanjang polis asuransi kesehatan di tahun 2020 yaitu sebesar $\mu_{i j}=$ 883.500 , sedangkan nilai rata-rata premi per bulan tertanggung yang tidak memperpanjang polis asuransi kesehatan di tahun 2020 yaitu sebesar $\mu_{i j}=1.014 .941$. Dengan nilai varians tertanggung yang memperpanjang polis asuransi kesehatan di tahun 2020 yaitu sebesar $\sigma^{2}{ }_{i j}=$ 719.258.750.000. Sedangkan, nilai varians tertanggung yang tidak memperpanjang polis asuransi kesehatan di tahun 2020 yaitu sebesar $\sigma^{2}{ }_{i j}=311.118 .058 .823$. Dihitung nilai fungsi probabilitas pembayaran premi per bulan untuk contoh tertanggung dengan pembayaran premi per bulan Rp.300.000,

$$
\begin{aligned}
& f(\text { Pembayaran Premi }=300.000 \mid \text { Perpanjang Polis })=\frac{1}{848.091 \sqrt{2 \pi}} e^{-\frac{(300.000-883.500)^{2}}{2(719.258 .750 .000)}} \\
& =3,7135 \times 10^{-7} \\
& f(\text { Pembayaran Premi }=300.000 \mid \text { Tidak Perpanjag Polis })=\frac{1}{557.779 \sqrt{2 \pi}} e^{-\frac{(300.000-1.014 .941)^{2}}{2(311.118 .058 .83)}}=3,1463 \times 10^{-7}
\end{aligned}
$$

Berdasarkan perhitungan di atas dapat dilihat bahwa tertanggung dengan pembayaran premi per bulan Rp.300.000 bersyarat perpanjang polis asuransi kesehatan di tahun 2020 memiliki nilai fungsi probabilitas sebesar $3,7135 \times 10^{-7}$. Sedangkan tertanggung dengan pembayaran premi per bulan Rp.300.000 bersyarat tidak perpanjang polis asuransi kesehatan di tahun 2020 memiliki nilai fungsi probabilitas sebesar 3,1463 $\times 10^{-7}$.

Langkah selanjutnya, akan dilakukan analisis data testing. Sebanyak 28 tertanggung yang termasuk dalam data testing akan diprediksi status perpanjang polisnya di tahun 2020 . Misalkan akan diprediksi status perpanjang polis untuk tertanggung dengan nomor tertanggung 10, berjenis kelamin laki-laki, usia 23 tahun, status penikahan belum menikah, tidak punya tanggungan, tidak merokok, premi per bulan sebesar Rp. 300.000 dan status pembayaran preminya lancar.

Dengan menggunakan informasi tersebut, dapat dihitung nilai probabilitas bersama untuk semua atribut data bagi tertanggung 10 bersyarat perpanjang polis dan bersyarat tidak perpanjang polis, masing-masing adalah

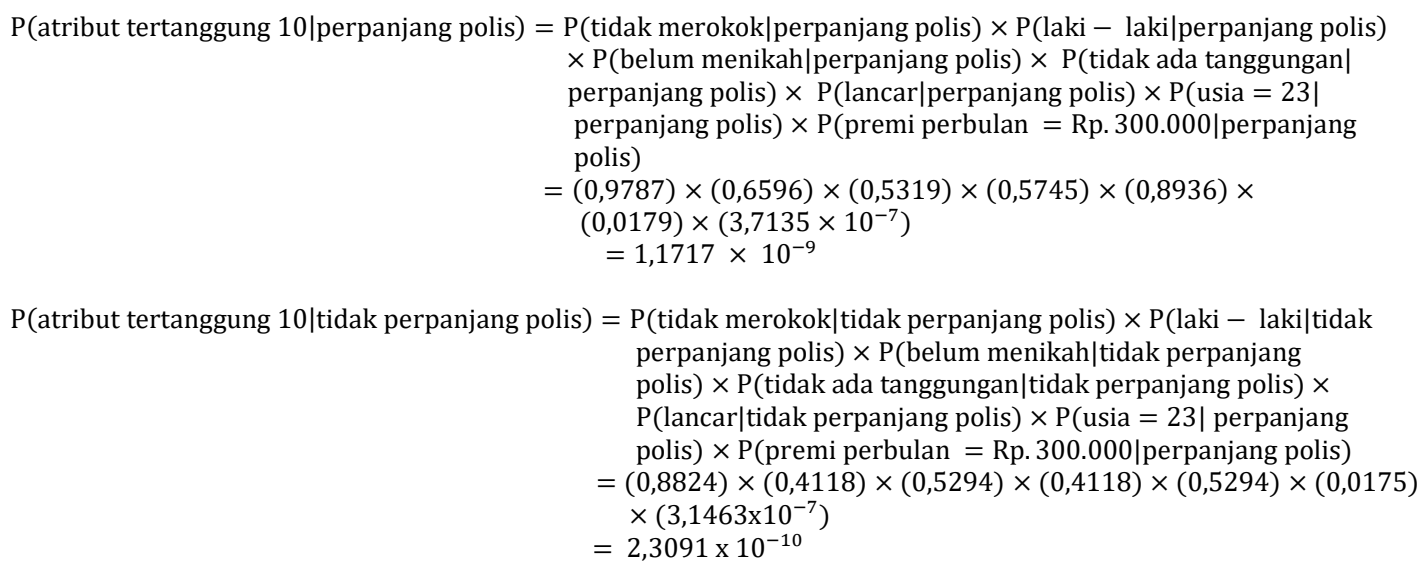


Dengan demikian didapat probabilitas posterior baik untuk perpanjang polis maupun untuk tidak perpanjang polis, yaitu

$\mathrm{P}$ (perpanjang polis|atribut tertanggung 10 )

$P$ (atribut tertanggung 10 perpanjang polis) $\times P$ (perpanjang polis)

$=\frac{}{P(\text { atribut tertanggung 10|perpanjang polis }) \times P(\text { perpanjang polis })+P(\text { atribut tertanggung } 10 \mid \text { tidak perpanjang polis }) \times P(\text { tidak perpanjang polis })}$

$=\frac{1,1717 \times 10^{-9} \times 0,7344}{1,1717 \times 10^{-9} \times 0,7344+2,3091 \times 10^{-10} \times 0,2656}=0,9335$

P(tidak perpanjang polis|atribut tertanggung 10)

$P$ (atribut tertanggung $10 \mid$ tidak perpanjang polis $) \times P$ (tidak perpanjang polis $)$

$=\overline{P(\text { atribut tertanggung 10|perpanjang polis }) \times P(\text { perpanjang polis })+P(\text { atribut tertanggung } 10 \mid \text { tidak perpanjang polis }) \times P(\text { tidak perpanjang polis })}$

$=\frac{\left.2,3091 \times 10^{-10}\right) \times 0,2656}{\left(1,1717 \times 10^{-9}\right) \times 0,7344+\left(2,3091 \times 10^{-10}\right) \times 0,2656}=0,0665$

Karena probabilitas posterior untuk perpanjang polis lebih besar dibandingkan dengan probabilitas posterior untuk tidak perpanjang polis, maka tertanggung 10 diklasifikasikan dalam kelas perpanjang polis. Langkah selanjutnya melakukan prediksi pada sisa polis lainnya yang ada di data testing. Tabel 6 menyajikan hasil prediksi status perpanjang polis dan status perpanjang polis sebenarnya untuk 28 tertanggung yang ada pada data testing. Hasil prediksinya diperoleh dengan bantuan perangkat lunak R. Studio 1.1.463.

Tabel 6 Data Prediksi Perpanjangan Polis Asuransi Kesehatan

\begin{tabular}{|l|l|l|l|}
\hline No & $\begin{array}{l}\text { Nama } \\
\text { Utama }\end{array}$ & $\begin{array}{l}\text { Presiksi } \\
\text { Perpanjangan }\end{array}$ & $\begin{array}{l}\text { Status Perpanjangan } \\
\text { Polis tahun 2020 }\end{array}$ \\
\hline 1 & Tertanggung 10 & Perpanjang Polis & Perpanjang Polis \\
\hline 2 & Tertanggung 14 & Tidak perpanjang Polis & Tidak perpanjang Polis \\
\hline 3 & Tertanggung 23 & Tidak perpanjang Polis & Perpanjang Polis \\
\hline 4 & Tertanggung 30 & Perpanjang Polis & Tidak perpanjang Polis \\
\hline 5 & Tertanggung 32 & Perpanjang Polis & Perpanjang Polis \\
\hline 6 & Tertanggung 35 & Perpanjang Polis & Perpanjang Polis \\
\hline 7 & Tertanggung 39 & Perpanjang Polis & Perpanjang Polis \\
\hline 8 & Tertanggung 40 & Perpanjang Polis & Perpanjang Polis \\
\hline 9 & Tertanggung 5 & Tidak perpanjang Polis & Tidak perpanjang Polis \\
\hline 10 & Tertanggung 51 & Perpanjang Polis & Perpanjang Polis \\
\hline 11 & Tertanggung 52 & Perpanjang Polis & Perpanjang Polis \\
\hline 12 & Tertanggung 54 & Perpanjang Polis & Perpanjang Polis \\
\hline 13 & Tertanggung 55 & Perpanjang Polis & Perpanjang Polis \\
\hline 14 & Tertanggung 57 & Perpanjang Polis & Perpanjang Polis \\
\hline 15 & Tertanggung 58 & Perpanjang Polis & Perpanjang Polis \\
\hline 16 & Tertanggung 59 & Perpanjang Polis & Perpanjang Polis \\
\hline 17 & Tertanggung 60 & Perpanjang Polis & Perpanjang Polis \\
\hline 18 & Tertanggung 62 & Tidak perpanjang Polis & Tidak perpanjang Polis \\
\hline 19 & Tertanggung 69 & Perpanjang Polis & Perpanjang Polis \\
\hline 20 & Tertanggung 70 & Tidak perpanjang Polis & Perpanjang Polis \\
\hline 21 & Tertanggung 77 & Perpanjang Polis & Perpanjang Polis \\
\hline 22 & Tertanggung 78 & Perpanjang Polis & Perpanjang Polis \\
\hline 23 & Tertanggung 82 & Perpanjang Polis & Perpanjang Polis \\
\hline 24 & Tertanggung 83 & Perpanjang Polis & Perpanjang Polis \\
\hline 25 & Tertanggung 86 & Tidak perpanjang Polis & Tidak perpanjang Polis \\
\hline 26 & Tertanggung 87 & Perpanjang Polis & Perpanjang Polis \\
\hline 27 & Tertanggung 88 & Perpanjang Polis & Perpanjang Polis \\
\hline 28 & Tertanggung 91 & Perpanjang Polis & Perpanjang Polis \\
\hline
\end{tabular}

Dibuat confusion matrix untuk melihat perbandingan hasil klasifikasi yang dilakukan oleh sistem (model) dengan klasifikasi sebenarnya. Tabel 7 menyajikan hasil confusion matrix yang diperoleh dengan bantuan perangkat lunak R. Studio 1.1.463. 
Tabel 7 Confusion Matrix

\begin{tabular}{|c|c|c|}
\hline Nilai Aktual & Perpanjang Polis & Tidak perpanjang Polis \\
\hline Perpanjang Polis & $\mathrm{TP}=21$ & $\mathrm{FP}=1$ \\
\hline Tidak perpanjang Polis & $\mathrm{FN}=2$ & $\mathrm{TN}=4$ \\
\hline
\end{tabular}

Berdasarkan Tabel 7 di atas dapat dilihat bahwa terdapat 21 tertanggung yang termasuk dalam True Positive (TP), artinya menurut data aktual ada sebanyak 21 tertanggung akan memperpanjang polis asuransi kesehatan dan dari model yang dibuat memprediksi bahwa 21 tertanggung ini akan memperpanjang polis asuransi kesehatan. Terdapat 4 tertanggung yang termasuk dalam True Negative (TN), artinya menurut data aktual ada sebanyak 4 tertanggung tidak akan memperpanjang polis asuransi kesehatan dan model yang dibuat memprediksi bahwa 4 tertanggung ini tidak akan memperpanjang polis asuransi kesehatan. Terdapat 1 tertanggung yang termasuk dalam False Positive (FP), artinya 1 tertanggung ini menurut data aktual akan memperpanjang polis asuransi kesehatan tetapi dari model yang dibuat memprediksi bahwa 1 tertanggung ini tidak akan memperpanjang polis asuransi kesehatan. Terdapat 2 tertanggung yang termasuk dalam False Negative (FN), artinya 2 tertanggung ini menurut data aktual tidak akan memperpanjang polis asuransi kesehatan tetapi dari model yang dibuat memprediksi bahwa 2 tertanggung ini akan memperpanjang polis asuransi kesehatan.

Selanjutnya akan dilakukan perhitungan performa Algoritma Nä̈ve Bayes Classifier. Ada 3 nilai yang akan dihitung yaitu nilai akurasi, presisi dan recall. Adapun nilai akurasinya adalah

$$
\begin{aligned}
& \text { Nilai akurasi }=\frac{\mathrm{TP}+\mathrm{TN}}{\mathrm{TP}+\mathrm{FP}+\mathrm{FN}+\mathrm{TN}}=\frac{21+4}{21+4+2+1}=\frac{25}{28}=0,8929 . \\
& \text { Nilai presisi }=\frac{\mathrm{TP}}{\mathrm{TP}+\mathrm{FP}}=\frac{21}{21+1}=\frac{21}{22}=0,9545 \\
& \text { Nilai recall }=\frac{\mathrm{TP}}{\mathrm{TP}+\mathrm{FN}}=\frac{21}{21+2}=\frac{21}{23}=0,9130
\end{aligned}
$$

Berdasarkan perhitungan di atas didapat nilai akurasi sebesar $89,29 \%$, yang artinya model secara akurat mengklasifikasikan status perpanjang polis tertanggung dengan benar sebanyak $89,29 \%$ dari seluruh tertanggung, dengan nilai presisi sebesar $95,45 \%$ dan nilai recall sebesar $91,30 \%$.

\section{Kesimpulan}

Pada artikel ini diterapkan Algoritma Nä̈ve Bayes Classifier dalam memprediksi status perpanjangan polis tertanggung asuransi kesehatan di PT. X berdasarkan data tertanggung di tahun 2020. Hasil penerapan Algoritma Nä̈ve Bayes Classifier menunjukan bahwa algoritma tersebut cukup baik dalam memprediksi status perpanjangan polis tertanggung asuransi kesehatan PT. X, dengan nilai akurasi sebesar 89,29\%, yang artinya model secara akurat mengklasifikasikan status perpanjang polis tertanggung dengan benar sebanyak $89,29 \%$ dari seluruh tertanggung, dengan nilai presisi sebesar $95,45 \%$ dan nilai recall sebesar $91,30 \%$.

\section{Acknowledge}

Penelitian ini dapat terlaksana dengan baik tentunya berkat bantuan dari berbagai pihak. Peneliti mengucapkan terimakasih kepada bapak Dr. Aceng Komarudin Mutaqin, MT., M.Si., para dosen statistika Uniba, rekan-rekan seperjuangan yaitu mahasiswa statistika atas bantuan, doa, dan bimbingannya.

\section{Daftar Pustaka}

[1] Kusrini \& Luthfi, E. T., Algoritma Data Mining. Andi Offset. Yogyakarta (2009).

[2] Patil, T.R., Sherekar, M. S. (2013). Performance Analysis of Nä̈ve Bayes and J48 Classification Algorithm for Data Classification, International Journal of Computer Science and Application, 6(2), 0974-1011.

[3] Bustami. (2014). Penerapan Algoritma Naïve Bayes untuk Mengklasifikasi Data Nasabah Asuransi. Jurnal Penelitian Teknik Informatika, Vol: 8 No.1. 
126 | Ajeng Mega Pratiwi, et al.

[4] Ignatius, R. Y. S. (2018). Pengantar Asuransi. Jakarta: ACA Asuransi.

[5] Kitab Undang-Undang Hukum Dagang (KUHD), Bab IX Tentang Asuransi atau Pertanggungan pada Umumnya, Pasal 246.

[6] N. Nuraeni, "Penentuan Kelayakan Kredit Dengan Algoritma Naïve Bayes Classifier: Studi Kasus Bank Maya pada Mitra Usaha Cabang PGC,” J. Tek. Komput. AMIK BSI, vol. 3, no. 1, pp. 9-15, 2017.

[7] . Hasymi Ali, Pengantar Asuransi, Bumi Aksara, Jakarta, 1993.

[8] Saruni D \& Yudo Devianto. (2019). Utilization of Prediction Data for Prospective Decision Customers Insurance Using the Classification Method of C.45 and Naive Bayes Algorithms. Journal of Phys.: Conf. Ser. 1179012023

[9] Natalius, Samuel, 2010, Metode Naive Bayes Classifier dan Penggunaannya Pada Klasifikasi Dokumen, Program Studi Sistem dan teknologi Informasi, Sekolah Teknik Elektro dan Informatika, Institut Teknologi Bandung.

[10] Manning, Christopher D. Raghavan, Prabhakar, Schütze, Hinrich (2009) An Introduction to Information Retrieval Cambridge University Press, Cambridge, England

[11] Saleh, A. (2015) Implementasi Metode Klasifikasi Nä̈ve Bayes Dalam Memprediksi Besarnya Penggunaan Listrik Rumah Tangga Citec Journal, Vol. 2, No. 3, ISSN: 23545771

[12] Abbas Salim, Dasar-dasar Asuransi, Tarisito, Bandung 1985.

[13] Kuncahyo S Nugroho (2019), Confusion Matrix untuk Evaluasi Model pada Supervised Learning. 